\title{
Spontaneous clearance of hepatitis $C$ virus in vertically infected children: any clue for treatment?
}

\author{
Giuseppe Indolfi • Elisa Bartolini • Massimo Resti
}

Received: 31 July 2011 /Accepted: 9 September 2011 / Published online: 20 September 2011

(C) Springer-Verlag 2011

To the Editor,

Farmand et al. published in the journal an interesting article on spontaneous clearance of hepatitis $\mathrm{C}$ virus $(\mathrm{HCV})$ in vertically infected children [2]. The authors state: "relatively little is known about the course of HCV infections acquired at or before birth." We believe that our 15-year retrospective/ prospective study of HCV infection in 504 children as well as other well-performed epidemiological studies can give some answers with regard to the prognosis of vertically acquired hepatitis C [1]. The cumulative probability of chronic progression of hepatitis $\mathrm{C}$ in children is around $80 \%$. Children with chronic hepatitis $\mathrm{C}$ are often asymptomatic, and end-stage liver disease is possible in a small subgroup (less than 5\%) characterized by perinatal exposure, maternal drug use, and infection with HCV genotype 1a [1].

The major aim of Farmand et al. [2] was to analyze individual cases of spontaneous clearance enrolling six children below 5 years of age in order to generate parameters to be tested in controlled therapeutic trials. The authors have confirmed previous findings showing that transaminases elevation is common in children who lost HVC RNA and that the mean age at observation of viral clearance is 40 months. However, by not reporting information about the IL-28B status, they have missed the opportunity to investigate the role of the emerging association between IL-28B polymorphisms and $\mathrm{HCV}$ clearance [3]. Of note, the authors have observed that spontaneous HCV clearance is possible beyond 3 years of age. We would like to highlight that the direct consequence of this result is that although the combined treatment for $\mathrm{HCV}$ infection has been approved for children starting from 3 years of age, it is strongly advised that clinicians wait in most children until the age of 5 years to start the treatment.

\section{References}

1. Bortolotti F, Verucchi G, Cammà C, Cabibbo G, Zancan L, Indolfi G, Giacchino R, Marcellini M, Marazzi MG, Barbera C, Maggiore G, Vajro P, Bartolacci S, Balli F, Maccabruni A, Guido M, Italian Observatory for HCV Infection and Hepatitis C in Children (2008) Long-term course of chronic hepatitis $\mathrm{C}$ in children: from viral clearance to end-stage liver disease. Gastroenterology 134:1900-1907

2. Farmand S, Wirth S, Löffler H, Woltering T, Kenzel S, Lainka E, Henneke P (2011) Spontaneous clearance of hepatitis C virus in vertically infected children. Eur J Pediatr (in press). doi:10.1007/s00431-011-1517-3

3. Ruiz-Extremera A, Muñoz-Gámez JA, Salmerón-Ruiz MA, de Rueda PM, Quiles-Pérez R, Gila-Medina A, Casado J, Belén Martín A, Sanjuan-Nuñez L, Carazo A, Pavón EJ, Ocete-Hita E, León J, Salmerón J (2011) Genetic variation in interleukin 28B with respect to vertical transmission of hepatitis $\mathrm{C}$ virus and spontaneous clearance in HCV-infected children. Hepatology 53:1830-1838 